\title{
Peranan Pejabat Pembuat Akta Tanah Dalam Pemungutan Bea Peralihan Hak Atas Tanah Dan Bangunan
}

\author{
Jemi Grahono Suryo Gupito \\ Fakultas Hukum Universitas Islam Indonesia Yogyakarta Indonesia \\ Jln. Cik Di Tiro No. 1 Yogyakarta Indonesia \\ grahonojemi@gmail.com
}

\begin{abstract}
This study aims to, first, analyze the role of Land Deed Making Officials (PPAT) in optimizing the collection of Transfer of Land and Building Rights (BPHTB) in order to achieve legal certainty in Sleman Regency. Second, identifying the obstacles for PPAT in optimizing BPHTB collection in order to realize legal certainty in Sleman Regency. This is a juridical empirical research, with a statutory approach. The results of the study conclude, first, as the vanguard of PPAT in optimizing BPHTB payments in Sleman Regency, namely providing accurate information to taxpayers about the basis for the imposition of BPHTB in accordance with the Sleman Regency Regional Regulation and appealing to prospective taxpayers to provide real information data on the amount of the sale and purchase price of land as the basis for the calculation of BPHTB tax. This is the key to creating legal certainty for the Sleman Regency government itself and taxpayers, the realization of this condition will lead optimiation of BPHTB collection in Sleman Regency. Second, obstacles come from taxpayers from taxpayer ignorance, past buying and selling transactions, to dishonesty from taxpayers in BPHTB payments. It is PPAT's duty to explain and escort taxpayers in the BPHB collection process to comply with the Sleman Regency Regional Regulation.
\end{abstract}

Key Words: BPHTB; legal certainty; PPAT

\begin{abstract}
Abstrak
Penelitian ini bertujuan untuk, pertama, menganalisis peran Pejabat Pembuat Akta Tanah (PPAT) dalam optimalisasi pemungutan Pemungutan Bea Peralihan Hak Atas Tanah dan Bangunan (BPHTB) guna mewujudkan kepastian hukum di Kabupaten Sleman. Kedua, mengetahui hambatan-hambatan bagi PPAT dalam pelaksanaan optimalisasi pemungutan BPHTB guna mewujudkan kepastian hukum di Kabupaten Sleman. Penelitian ini merupakan penelitian yang bersifat yuridis empiris, dengan pendekatan perundang-undangan. Hasil penelitian menyimpulkan, pertama, sebagai garda terdepan PPAT dalam optimalisasi pembayaran BPHTB di Kabupaten Sleman yaitu memberikan informasi yang akurat kepada wajib pajak tentang dasar pengenaan BPHTB yang sesuai dengan Peraturan Daerah Kabupaten Sleman dan menghimbau kepada calon wajib pajak untuk memberikan data informasi yang riil akan besaran harga jual beli tanah sebagai dasar pengenaan dalam penghitungan pajak BPHTB. Hal ini menjadi kunci terciptanya kepastian hukum bagi pihak pemerintah daerah kabupaten Sleman sendiri maupun pihak wajib pajak, apabila kondisi ini dapat diwujudkan maka akan tercipta optimalisasi pemungutan BPHTB di Kabupaten Sleman. Kedua, hambatan berasal dari wajib pajak dari ketidaktahuan wajib pajak, transaksi jual beli yang lampau, sampai pada ketidakjujuran dari wajib pajak dalam pembayaran BPHTB. Menjadi tugas PPAT untuk menjelaskan dan mengawal wajib pajak dalam proses pemungutan BPHB agar sesuai dengan Perda Kabupaten Sleman.
\end{abstract}

Kata-kata Kunci: BPHTB; kepastian hukum; PPAT 


\section{Pendahuluan}

Penerapan otonomi daerah tidak dapat dipungkiri telah memberi dampak besar bagi proses pengelolaan keuangan daerah oleh pemerintah daerah masingmasing. Terutama berkaitan dengan wewenang mengelola sumber-sumber pendapatan.Salah satunya dapat dilihat dari pelimpahan wewenang pemungutan Bea Peralihan Hak atas Tanah dan Bangunan (BPHTB). Undang-Undang Nomor 20 Tahun 2000 tentang Bea Perolehan Hak Atas Tanah dan Bangunan pada Pasal 1 angka 1 menyebutkan bahwa BPHTB merupakan pajak yang dikenakan atas perolehan hak atas tanah dan atau bangunan.

Seiring dengan perkembangan penerapan otonomi daerah, maka wewenang pemungutan BPHTB dilimpahkan ke pemerintah daerah. Hal tersebut diatur dalam Undang-Undang Nomor 28 Tahun 2009 tentang Pajak Daerah dan Retribusi Daerah (selanjutnya disebut UU tentang PDRD). Berdasarkan peraturan tersebut, BPHTB dialihkan menjadi pajak daerah yang pemungutannya diserahkan kepada Pemerintah Kota atau Kabupaten. Secara jelas dan rinci posisi BPHTB sebagai bagian dari sumber pendapatan daerah diatur dalam bagian ketujuhbelas Pasal 85-93 UU tentang PDRD. Menurut ketentuan tersebut, BPHTB dikenakan bukan hanya pada saat terjadinya jual beli tanah, tetapi juga terhadap setiap perolehan hak atas tanah dan bangunan (tukar menukar, hibah, waris, pemasukan tanah ke dalam perseroan, dan lain-lain).

Peralihan wewenang pemungutan BPHTB dari pemerintah pusat ke pemerintah daerah dapat dilihat sebagai salah satu upaya untuk mengoptimalkan pendapatan daerah melalui BPHTB. Termasuk dalam hal ini adalah menggali potensi BPHTB sebagai bagian dari pajak daerah secara lebih optimal. ${ }^{1}$

Perolehan hak atas tanah dan bangunan sendiri dapat terjadi karena adanya peralihan hak yang meliputi peristiwa hukum atau perbuatan hukum tertentu yang terjadi antara orang atau badan hukum sebagai subjek hukum yang oleh undang-undang dan peraturan hukum diberi kewenangan untuk memiliki hak atas tanah dan bangunan, dan menurut hukum peralihan hak terjadi karena dua hal yaitu hak beralih dan hak dialihkan.2 Berdasarkan Pasal 86 ayat (2) UndangUndang tentang PDRD, dapat diketahui bahwa objek pajak BPHTB sendiri meliputi pemindahan hak dan pemberian hak baru. Ketentuan tersebut semakin memperjelas batas wewenang pemerintah daerah dalam melakuan pemungutan BРНTВ.

Marihot Pahalamana Siahaan, Bea Perolehan Hak Atas Tanah dan Bangunan: Teori dan Praktek, RajaGrafindo Persada, Jakarta, 2003, hlm. 6.

IIbid., hlm. 61. 
Sementara untuk BPHTB sendiri, mekanisme pemungutannya diatur melalui sistem self assessment. Sistem self assessment adalah suatu sistem perpajakan dimana inisiatif untuk memenuhi kewajiban perpajakan berada di Wajib Pajak. Kelemahan dari sistem ini adalah karena sistem self efektvitas pemungutannya sangat tergantung pada kejujuran wajib pajak. PPAT Kabupaten Sleman yang secara langsung berhadapan dengan calon wajib pajak akan sangat berperan dalam optimalisasi pemungutan BPHTB di Kabupaten Sleman.

\section{Rumusan Masalah}

Berdasarkan latar belakang yang telah diuraikan, maka rumusan masalah dalam penelitian ini adalah pertama, bagaimana peran PPAT dalam optimalisasi pemungutan BPHTB guna mewujudkan kepastian hukum di Kabupaten Sleman? Kedua, apa saja hambatan bagi PPAT dalam pelaksanaan optimalisasi pemungutan BPHTB guna mewujudkan kepastian hukum di Kabupaten Sleman?

\section{Tujuan Penelitian}

Tujuan dari penelitian ini adalah sebagai berikut. Pertama, menganalisis peran PPAT dalam optimalisasi pemungutan BPHTB guna mewujudkan kepastian hukum di Kabupaten Sleman. Kedua, mengetahui hambatan-hambatan bagi PPAT dalam pelaksanaan optimalisasi pemungutan BPHTB guna mewujudkan kepastian hukum di Kabupaten Sleman.

\section{Metode Penelitian}

Penelitian ini merupakan penelitian yang bersifat yuridis empiris, yaitu penelitian yang dilakukan dengan cara meneliti bahan pustaka yang merupakan sumber data sekunder atau disebut dengan penelitian kepustakaan, selanjutnya untuk menunjang dan melengkapi data sekunder tersebut, maka dilakukan pula penelitian lapangan sehingga diperoleh data primer. $^{3}$ Penelitian terhadap kenyataan yang terjadi dilapangan disebut juga dengan penelitian empiris, penelitian yuridis empiris memungkinkan dilakukannya telaah Undang-Undang atau regulasi yang bersangkut paut dengan permasalahan hukum secara empiris. Hasil dari telaah tersebut dapat dipergunakan untuk memecahkan permasalahan hukum yang diteliti. ${ }^{4}$ Dalam penelitian ini maka penulis melakukan analisis mengenai peranan PPAT dalam optimalisasi pemungutan BPHTB guna

${ }^{3}$ Soerjono Soekanto, Pengantar Penelitian Hukum, UI Press, Jakarta, 2002, hlm. 52.

${ }^{4}$ Zainuddin Ali, Metode Penelitian Hukum, Sinar Grafika, Jakarta, 2009, hlm. 105. 
mewujudkan kepastian hukum di Kabupaten Sleman berdasarkan peraturan perundang-undangan yang berlaku dan akan melakukan penelitian lapangan untuk mendapatkan data primer.

Pendekatan yang digunakan dalam penulisan hukum menurut Peter Mahmud Marzuki adalah sebagai berikut: ${ }^{5}$
a. Pendekatan Kasus (Case approach)
b. Pendekatan Perundang-Undangan (Statute approach)
c. Pendekatan Historis (Historical approach)
d. Pendekatan Perbandingan (Comparative approach)
e. Pendekatan Konseptual (Conceptual approach)

Adapun pendekatan yang digunakan penulis dari beberapa pendekatan di atas adalah pendekatan perundang-undangan. Pendekatan perundang-undangan adalah pendekatan yang dilakukan dengan menelaah semua undang-undang dan regulasi yang bersangkut paut dengan isu hukum yang ditangani. Dalam hal ini yang bersangkutan dengan pemungutan BPHTB di Kabupaten Sleman, yaitu Peraturan Daerah Kabupaten Sleman Nomor 14 Tahun 2010 tentang BPHTB.

Studi dokumen merupakan proses mencari, mengumpulkan, dan mempelajari berbagai sumber data sekunder yang berhubungan dengan objek penelitian dengan bantuan buku-buku, literatur, peraturan perundang-undangan, dan dokumen-dokumen lainnya. ${ }^{6}$

\section{Hasil Penelitian dan Pembahasan}

\section{Tugas Pokok dan Wewenang PPAT}

Tugas pokok dan wewenang PPAT secara jelas diatur dalam Peraturan Pemerintah Nomor 37 Tahun 1998 tentang Peraturan Jabatan Pejabat Pembuat Akta Tanah. Tugas Pokok PPAT berdasarkan ketentuan Pasal 2 ayat (1) dan ayat (2) PP tersebut adalah sebagai berikut:

a. PPAT bertugas pokok melaksanakan sebagian pendaftaran tanah dengan membuat akta sebagai bukti telah dilakukannya perbuatan hukum tertentu mengenai hak atas tanah atau Hak Milik Atas Satuan Rumah Susun, yang akan dijadikan dasar bagi pendaftaran perubahan data pendaftaran tanah yang diakibatkan oleh perbuatan hukum itu.

b. Perbuatan hukum sebagaimana dimaksud dalam ayat (1) adalah sebagai berikut:

1. Jual beli;

2. Tukar menukar;

3. Hibah;

5 Peter Mahmud Marzuki, Penelitian Hukum, Kencana Prenada Media Grup, Jakarta, 2011, hlm. 93.

${ }^{6}$ Ibid., hlm. 12. 
4. Pemasukan dalam perusahaan tertentu;

5. Pembagian hak bersama;

6. Pemberian Hak Guna Bangunan/Hak Pakai atas Tanah Hak Milik;

7. Pemberian Hak Tanggungan;

8. Pemberian Kuasa memberikan Hak Tanggungan.

Ketentuan tersebut menunjukkan beberapa tugas pokok PPAT. Dapat dilihat bahwa tugas pokok PPAT adalah membuat akta sebagai bukti telah dilakukan perbuatan hukum tertentu mengenai hak atas tanah atau Hak Milik Atas Satuan Rumah Susun yang dijadikan dasar bagi pendaftaran perubahan data pendaftaran tanah yang meliputi jual beli, tukar menukar, hibah, pemasukan dalam perusahaan tertentu, pembagian hak bersama, pemberian Hak Guna Bangunan/Hak Pakai atas Tanah Hak Milik, pemberian Hak Tanggungan, serta pemberian Kuasa memberikan Hak Tanggungan.

Sementara itu, wewenang PPAT diatur dalam ketentuan Pasal 3 ayat (1) Peraturan Pemerintah Nomor 37 Tahun 1998 tentang Peraturan Jabatan Pejabat Pembuat Akta Tanah. Wewenang PPAT tersebut yaitu:

Untuk melaksanakan tugas pokok sebagaimana dimaksud dalam pasal 2 seseorang PPAT mempunyai kewenangan membuat akta otentik mengenai semua perbuatan hukum sebagaimana dimaksud dalam Pasal 2 ayat (2) mengenai hak atas tanah dan Hak Milik Atas Satuan Rumah Susun yang terletak di dalam daerah kerjanya.

Berdasarkan ketentuan Pasal 3 ayat (1) Peraturan Pemerintah Nomor 37 Tahun 1998 tentang Peraturan Jabatan Pejabat Pembuat Akta Tanah tersebut, maka dapat dilihat bahwa kewenangan PPAT adalah sebagai pejabat yang membantu Kepala Kantor Pertanahan Kabupaten/Kalurahan dalam melaksanakan sebagian pendaftaran tanah dan membuat akta otentik tentang perbuatan hukum atas tanah sebagai perubahan penguasaan atas tanah di dalam daerah kerjanya.

Tugas pokok dan wewenang tersebut melekat pada kedudukan PPAT sebagai pejabat pembuat akta otentik yang berkaitan dengan hak-hak atas tanah.Oleh sebab itu, pelaksanaan tugas pekerjaan PPAT di dalam daerah kerjanya harus mengacu pada tugas pokok dan wewenang tersebut.

\section{Ketentuan yang Berkaitan dengan BРНTB di Kabupaten Sleman}

Daerah Kabupaten Sleman merupakan kawasan dengan perkembangan nilai jual tanah yang sangat cepat di provinsi Daerah Istimewa Yogyakarta. Seiring dengan penerapan otonomi daerah, maka wewenang pemungutan BРНTB 
dilimpahkan ke Pemerintah Daerah sesuai dengan Undang- Undang Nomor 28 Tahun 2009 pajak daerah dan retribusi daerah. BРHTB sebagai bagian dari sumber pendapatan daerah dikenakan bukan hanya pada saat terjadinya jual beli saja akan tetapi terhadap setiap perolehan hak atas tanah dan bangunan, seperti pada peristiwa hukum tukar-menukar, hibah, waris, pemasukan tanah ke dalam perseroan dan lain- lain. Untuk menggali BPHTB sebagai bagian dari pendapatan daerah secara lebih optimal maka dibuatlah Peraturan Daerah Kabupaten Sleman Nomor 14 Tahun 2010 tentang aturan pemungutan BPHTB di Kabupaten Sleman.

Pasal-pasal dalam Peraturan Daerah Nomor 14 Tahun 2010 Kabupaten Sleman yang berkaitan dengan BPHTB antara lain:

a. Pasal 3 ayat (2), yang menyatakan bahwa objek pajak adalah perolehan hak atas tanah dan atau bangunan. Perolehan hak atas tanah dan/ atau bangunan meliputi:

1) pemindahan hak karena:

a) jual beli

b) tukar menukar

c) hibah

d) hibah wasiat

e) waris

f) pemasukan dalam perseroan atau badan hukum lain

g) pemisahan hak ya g mengakibatkan peralihan

h) penunjukan pembeli dalam lelang

i) pelaksanaan putusan hakim yang mempunyai kekuatan hukum tetap

j) penggabungan usaha

k) peleburan usaha

1) pemekaran usaha

m) hadiah

2) pemberian hak baru karena:

a) kelanjutan pelepasan hak; atau

b) diluar pelepasan hak

b. Pasal 3 ayat (3), menyatakan bahwa hak atas tanah dan bangunan sebagaimana yang dimaksud pada ayat (2) meliputi:

1) hak milik

2) hak guna usaha

3) hak guna bangunan

4) hak pakai

5) hak milik atas satuan rumah susun, dan

6) hak pengelolaan

c. Pasal 4, menyatakan bahwa objek pajak yang tidak dikenakan bea perolehan hak atas tanah dan bangunan adalah objek pajak yang diperoleh:

1) perwakilan diplomatik atas asas perlakuan timbal balik

2) negara untuk menyelenggarakan pemerintahan dan/ atau untuk pelaksanaan pembangunan guna kepentingan umum 
3) badan atau perwakilan lembaga internasional yang ditetapkan dengan peraturan menteri keuangan dengan syarat tidak menjalankan usaha atau melakukan kegiatan lain diluar fungsi dan tugas badan atau perwakilan organisasi tersebut.

4) orang pribadi atau badan karena konversi hak atau karena perbuatan hukum lain dengan tidak adanya perubahan nama.

5) orang pribadi atau badan karena wakaf.

6) orang pribadi atau badan yang digunakan untuk kepentingan ibadah.

d. Pasal 5, yang menyatakan bahwa subjek pajak adalah orang pribadi atau badan yang memperoleh hak atas tanah dan/ atau bangunan.

e. Pasal 6, yang menyatakan bahwa wajib pajak adalah orang pribadi atau badan yang memperoleh hak atas tanah dan/ atau bangunan.

f. Pasal 7, yang menyatakan tentang dasar pengenaan pajak, yaitu:

1) jual beli berdasarkan harga transaksi

2) tukar menukar berdasarkan nilai pasar

3) hibah berdasarkan nilai pasar

4) hibah wasiat berdasarkan nilai pasar

5) waris berdasarkan nilai pasar

6) pemasukan dalam perseroan atau badan hukum lainnya adalah nilai pasar.

7) pemisahan hak yang mengakibatkan peralihan adalah nilai pasar.

8) peralihan hak karena pelaksanaan putusan hakim yang mempunyai kekuatan hukum tetap adalah nilai pasar.

9) pemberian hak baru atas tanah sebagai kelanjutan dari pelepasan hak adalah nilai pasar.

10) pemberian hak baru atas tanah diluar pelepasan hak adalah nilai pasar.

11) penggabungan usaha adalah nilai pasar.

12) peleburan usaha adalah nilai pasar.

13) pemekaran usaha adalah nilai pasar

14) hadiah adalah nilai pasar

15) penunjukan pembeli dalam lelang adalah nilai harga transaksi yang tercantum dalam risalah lelang.

g. Pasal 8, yang menyatakan bahwa besaran NPOPTKP ditetapkan sebesar Rp $60.000 .000,00$ (enam puluh juta rupiah) untuk setiap wajib pajak. Khusus untuk perolehan hak atas tanah dan/ bangunan yang masih dalam hubungan keluarga sedarah dalam garis keturunan lurus satu derajat keatas atau satu derajat kebawah dengan pemberian hibah wasiat termasuk suami atau istri, NPOPTKP-nya ditetapkan sebesar Rp $300.000 .000,00$ (tiga ratus juta rupiah)

h. Pasal 9, yang menyatakan bahwa tarif pajak ditetapkan sebesar 5\% (lima persen), khusus untuk waris dan hibah wasiat ditetapkan sebesar 2,5\% (dua setengah persen). 
i. Pasal 10, menyatakan bahwa besaran pokok pajak yang terhutang dihitung dengan cara mengalikan tarif pajak dengan nilai pasar setelah dikurangi dengan NPOPTKP.

j. Pasal 12 ayat (1), menyatakan bahwa saat terutangnya pajak ditetapkan untuk:

1) jual beli adalah sejak tanggal dibuat dan ditandatanganinya akta.

2) tukar menukar adalah sejak tanggal dibuat dan ditandatanganinya akta

3) hibah adalah sejak tanggal dibuat dan ditandatanganinya akta

4) hibah wasiat adalah sejak tanggal dibuat dan ditandatanganinya akta

5) waris adalah sejak tanggal yang bersangkutan mendaftarkan peralihan haknya ke Kantor Bidang Pertanahan.

6) lelang adalah sejak tanggal penunjukan pemenang lelang.

k. Pasal 13 ayat (3), yang menyatakan bahwa SSPD wajib diisi dengan jelas, benar, dan lengkap serta ditandatangani oleh wajib pajak.

1. Pasal 29 ayat (2), menyatakan bahwa penelitian SSPD dilakukan antara lain terhadap:

1) tarif dan NPOPTKP

2) adanya kepastian bahwa wajib pajak telah membayar pajak BPHTB atau telah disetor ke kas daerah/ bank yang ditunjuk

3) Keseuaian objek pajak dengan data basis pajak.

m.Pasal 31 ayat (1), menyatakan bahwa Pejabat Pembuat Akta Tanah/ Notaris hanya dapat menandatangani akta pemindahan hak atas tanah dan/ atau bangunan setelah wajib pajak menyerahkan bukti pembayaran pajak berupa SSPD.

n. Pasal 32 ayat (1), menyatakan bahwa Pejabat Pembuat Akta Tanah (PPAT) atau Notaris dan kepala kantor yang membidangi pelayanan lelang negara melaporkan pembuatan akta atau risalah lelang perolehan hak atas tanah dan/ atau bangunan kepada Bupati paling lambat tanggal 10 (sepuluh) bulan berikutnya.

o. Pasal 33 ayat (1), menyatakan bahwa Pejabat Pembuat Akta Tanah/ Notaris dan kepala kantor yang membidangi lelang negara, yang melanggar ketentuan pasal 31 ayat (1) dikenakan sanksi administratif berupa denda sebesar Rp. 7.500.000,00 (Tujuh juta lima ratus ribu rupiah) untuk setiap pelanggaran.

p. Pasal 33 ayat (2), menyatakan bahwa Pejabat Pembuat Akta Tanah/ Notaris yang melanggar ketentuan dalam Pasal 32 ayat (1) dikenakan sanksi administratif berupa denda sebesar Rp. 250.000,00 (Dua ratus lima puluh ribu rupiah).

q. Pasal 36 ayat (1), menyatakan bahwa wajib pajak yang karena kealpaannya tidak menyampaikan SSPD atau mengisi dengan tidak benar atau tidak lengkap atau melampirkan keterangan yang tidak benar sehingga merugikan keuangan daerah dapat dipidana dengan pidana kurungan paling lama satu tahun atau pidana denda paling banyak dua kali jumlah pajak yang terutang yang tidak atau kurang dibayar.

r. Pasal 36 ayat (2), menyatakan bahwa wajib pajak wajib pajak yang karena kealpaannya tidak menyampaikan SSPD atau mengisi dengan tidak benar 
atau tidak lengkap atau melampirkan keterangan yang tidak benar sehingga merugikan keuangan daerah dapat dipidana dengan pidana kurungan paling lama dua tahun atau pidana denda paling banyak empat kali jumlah pajak yang terutang yang tidak atau kurang dibayar.

\section{Mekanisme Validasi BPHTB di Kabupaten Sleman}

Bea Perolehan Hak atas Tanah dan Bangunan merupakan salah satu pajak daerah di Kabupaten Sleman, yang pemungutannya dibebankan kepada wajib pajak yang hendak melakukan peralihan hak berupa tanah dan/ atau bangunan. Proses peralihan hak atas tanah dan bangunan dapat dilakukan melalui salah satu proses peralihan, yaitu jual beli, tukar menukar, hibah, hibah wasiat, waris, pemasukan dalam perseroan atau badan hukum lainnya, pemisahan hak yang mengakibatkan peralihan, peralihan hak karena pelaksanaan putusan hakim, pemberian hak baru atas tanah diluar pelepasan, penggabungan usaha, peleburan usaha, hadiah, serta penunjukan pembeli dalam lelang.

Proses Pemungutan BPHTB di Kabupaten Sleman dalam semua transaksi jual beli, hibah, waris, dan lain sebagainya saat ini dilakukan melalui sistem layanan berbasis online. Sistem layanan online tersebut dapat diakses oleh masyarakat dan Pejabat Pembuat Akta Tanah (PPAT) dengan login terlebih dahulu pada alamat website www.bphtb.slemankab.go.id. PPAT menjadi salah satu pejabat yang memiliki kewenangan dalam legalisasi berkas pengajuan pajak BPHTB, sehingga PPAT secara langsung dapat memberikan masukan informasi kepada wajib pajak dalam perhitungan pajak BPHTB. Berdasarkan pasal 29 ayat 2 dalam perda BPHTB kabupaten sleman bahwa pengajuan SSPD wajib pajak tidak serta merta langsung disetujui tetapi diteliti terlebih dahulu kesesuaian objek pajak dengan data basis pajak BKAD Kabupaten Sleman. Pengajuan SSPD wajib pajak harus diisi dan dihitung dengan benar agar tidak merugikan pendapatan Daerah Kabupaten Sleman. Penyambung penyampaian informasi tentang kesesuaian tarif objek pajak dengan data basis pajak DPKAD Kabupaten Sleman dengan wajib pajak adalah tugas dari PPAT sebagai garda terdepan yang berhadapan langsung dengan wajib pajak agar tercipta optimalisasi penerimaan pajak BPHTB dan melindungi kepastian hukum wajib pajak. hal ini sesuai dengan Pasal 36 ayat (1 dan 2), dalam Perda BPHTB Kabupaten sleman Pasal 36 ayat (1) yang menyebutkan bahwa wajib pajak yang karena kealpaanya tidak menyampaikan SSPD atau mengisi dengan tidak benar dan atau tidak lengkap atau melampirkan keterangan yang tidak benar sehingga merugikan keuangan daerah dapat dipidana dengan pidana denda paling banyak 2 kali jumlah pajak 
yang terutang yang tidak atau kurang bayar, serta berdasarkan Pasal 36 ayat (2) yang menyebutkan bahwa wajib pajak yang karena kealpaanya tidak menyampaikan SSPD atau mengisi dengan tidak benar dan atau tidak lengkap atau melampirkan keterangan yang tidak benar sehingga merugikan keuangan daerah dapat dipidana dengan pidana penjara paling lama 2 tahun atau pidana denda paling banyak 4 kali jumlah pajak yang terutang yang tidak atau kurang bayar. Untuk menghindari kesalahan dalam penghitungan pajak BPHTB yang dilakukan oleh wajib pajak maka peran PPAT Kabupaten Sleman menjadi mutlak dibutuhkan sebagai jembatan penyambung memberikan informasi kepada wajib pajak tentang penghitungan BPHTB yang terutang secara benar yang sesuai dengan Perda BPHTB Kabupaten Sleman sehingga wajib pajak terhindar dari ancaman pidana berdasarkan Pasal 36 ayat (1 dan 2) dalam Perda BPHTB Kabupaten Sleman. Apabila proses Pengajuan BPHTB dari wajib pajak tidak ada hambatan dan telah diteliti dan divalidasi oleh BKAD Kabupaten Sleman yang sesuai dengan Perda BPHTB maka tugas pokok dan wewenang PPAT sesuai Peraturan Pemerintah Nomor 37 Tahun 1998 dapat cepat dilaksanakan yaitu dengan melaksanakan sebagian pendaftaran tanah dengan membuat akta sebagai bukti dilakukannya perbuatan hukum tertentu mengenai hak atas tanah atau Hak milik Atas Satuan Rumah Susun, yang akan dijadikan dasar bagi pendaftaran perubahan data pendaftaran tanah yang diakibatkan oleh perbuatan hukum tersebut. Hal ini sesuai dengan Perda Kabupaten Sleman Pasal 31 ayat (1) yang menyatakan bahwa Pejabat Pembuat Akta Tanah hanya dapat menandatangani akta pemindahan hak atas tanah dan atau bangunan setelah wajib pajak menyerahkan bukti pembayaran pajak SSPD yang telah diteliti dan divalidasi oleh BKAD Kabupaten Sleman.

Pada transaksi jual beli, yang dilakukan wajib dalam pembayaran pajak BPHTB pertama kali yaitu megajukan harga transaksi yang telah disepakati oleh para pihak (penjual dan pembeli) melalui situs www.bphtb.slemankab.go.id, Pengajuan harga transaksi tersebut dapat dilakukan pada PPAT yang mendapatkan kuasa dari wajib pajak. Selain pengajuan harga, disertakan pula dokumen-dokumen pendukung, diantaranya sertifikat, PBB, titik ordinat bidang tanah, TM Converter, Gambar objek, surat keterangan beda nama (jika ada), Setelah pengajuan tersebut dikirim, selanjutnya akan dilakukan penelitian oleh pihak BKAD Kabupaten Sleman, apakah pengajuan harga transaksi tersebut wajar atau tidak. Jika penilaiannya menyatakan tidak wajar, maka akan diterbitkan berita acara kurang bayar. Sebaliknya jika penelitian terhadap pengajuan harga transaksi tersebut dinilai wajar, maka akan diterbitkan surat perintah bayar berupa Surat Setor Pajak Daerah Bea Perolehan Hak atas Tanah 
dan Bangunan (SSPD-BPHTB). SSPD BPHTB dicetak rangkap 5, dengan pembagian lembar 1 untuk wajib pajak, lembar 2 untuk PPAT, lembar 3 untuk BPN, lembar 4 untuk BKAD, dan lembar 5 untuk Bank.?

Printout atau blanko pembayaran SSPD BPHTB wajib ditandatangani oleh wajib pajak dan PPAT.Pembayaran dilakukan di bank yang ditunjuk, salah satunya yaitu Bank BPD DIY. Teller atau Pihak Bank BPD akan mengambil printout SSPD-BPHTB lembar 5. Selanjutnya lembar 1, 2, 3, 4 dibawa oleh wajib pajak untuk diserahkan ke BKAD Kabupaten Sleman untuk dicap dan ditandatangani oleh pejabat BKAD Kabupaten Sleman yang berwenang. Selang waktu 1 hari, pemohon atau kuasanya mengambil kembali lembar SSPD-BPHTB yang telah divalidasi oleh pejabat BKAD Kabupaten Sleman, yaitu lembar 1, 2, dan 3. Selanjutnya lembar 1, 2, dan 3 diserahkan kepada PPAT untuk proses validasi pembayaran $\mathrm{PPh}$ dan penandatanganan akta jual beli.

\section{Hambatan-hambatan bagi PPAT dalam Optimalisasi BPHTB di Kabupaten Sleman}

Hambatan pertama yaitu ketidaktahuan wajib pajak tentang tata cara penghitungan pembayaran pajak BPHTB yang terutang menjadi salah satu permasalahan bagi PPAT, PPAT dibuat bingung dalam menentukan dasar pengenaan pajak BPHTB apakah berdasarkan harga transaksi riil jual beli atau berdasarkan zona nilai tanah yang ditetapkan oleh pihak BKAD Kabupaten Sleman sendiri hal ini disebabkan karena kurangnya sosialisasi dari pihak pemerintah daerah tentang dasar penghitungan BРНTB khususnya BРНTB peralihan hak jual beli.

Hambatan kedua banyak terjadi transaksi jual beli yang lampau tapi pengurusan balik namanya baru dilakukan pada tahun berjalan ini. Seringkali PPAT harus menerangkan dan menjelaskan serta menghitungkan berapa pajak terutang yang harus dibayarkan dengan dasar nilai jual pasar pada tahun berjalan ini sesuai dengan harga riil jual beli lampau waktu yang disesuaikan dengan perkiraan nilai pasar pada tahun berjalan ini, apabila telah diperoleh penghitungan berapa besarnya pajak yang terutang seringkali wajib pajak merasa keberatan dengan jumlah pajak BPHTB yang harus dibayar, hal ini disebabkan oleh ketidaktahuan wajib pajak atau pihak pembeli yang beranggapan bahwa dasar pengenaan pajak BPHTB jual belinya berdasarkan harga riil yang terjadi pada lampau waktu itu. Padahal nilai pasar objek pajak setiap tahun pasti akan bertambah naik harganya.Untuk itu perlu adanya penyesuaian dasar pengenaan

${ }^{7}$ Wawancara dengan Heti, SH, PPAT Kabupaten Sleman, pada tanggal 8 Juli 2020. 
pajak BPHTB yang bukan lagi berdasarkan harga transaksi jual beli masa lampau tetapi berdasarkan harga transaksi yang disesuaikan dengan nilai pasar tahun berjalan ini. Kemudian terjadilah perundingan ulang lagi antara pihak penjual dan pembeli tentang kesepakatan BPHTB apakah akan dibagi sama rata atau tetap menjadi tanggungjawab dari pihak pembeli saja. Perundingan yang dilakukan berualng-ulang mengakibatkan waktu proses pembuatan dan penandatanganan balik nama menjadi lebih lama. Tidak adanya kepastian tentang dasar pengenaan BPHTB inilah yang menyebabkan kurang optimal dan evisien dalam penghitungan pemungutan BPHTB Kabupaten Sleman.

Hambatan Ketiga yaitu wajib pajak yang sudah tahu tata cara penghitungan dan pembayaran BPHTB malah mencari celah keringanan dalam pembayaran BPHTB yaitu dengan cara memberikan informasi tentang harga transaksi jual beli yang tidak riil kepada PPAT, pihak penjual dan pembeli telah merekayasa harga jual beli dengan membuat sendiri kwitansi transaksi jual beli yang tidak riil kemudian baru menghadap kepada PPAT padahal dalam kenyataannya harga sebenarnya jual beli tersebut lebih tinggi daripada kwitansi jual beli rekayasa yang telah mereka buat untuk dasar pengenaan penghitungan BPHTB. Sebagai contoh harga jual beli tanah riil Rp. 260.000.000,00 dibuat kwitansi jual beli fiktif sebesar Rp. 160.000.000,00, maka penghitungan BPHTBnya menjadi berkurang sebesar 50 persen yang seharus membayar pajak Rp. 10.000.000,00 ((Rp. 260.000.000,00 - Rp. 60.000.000,00) X 5 \%) menjadi hanya membayar Rp. 5.000.000,00 ((Rp. 160.000.000,00 - Rp. 60.000.000,00) X5\%). Hal ini terjadi karena lemahnya sanksi yang berjalan selama ini berdasarkan Perda Kabupaten Sleman Nomor 14 Tahun 2010 Bab XVII Pasal 36 yaitu apabila ada rekayasa dan kealpaan dalam penghitungan BPHTB maka akan diberikan Sanksi pidana berupa kurungan penjara 1 tahun atau denda berupa 2 kali dari pajak BPHTB yang terutang. ${ }^{8}$ Apabila terindikasi adanya rekayasa dalam penghitungan pajak yang tidak sesuai dengan hasil penelitian dari pihak BKAD maka berkas permohonan online dari wajib pajak hanya ditolak dan dikembalikan kepada wajib pajak dengan diterbitkanya berita acara kurang bayar yang sesuai dengan penghitungan zona nilai tanah menurut BKAD Kabupaten Sleman. Apabila wajib pajak setuju dengan penghitungan BPHTB berdasarkan zona nilai tanah dari BKAD Kabupaten Sleman selanjutnya wajib pajak melakukan pembayaran BPHTB di Bank BPD DIY. Sebaliknya apabila wajib pajak tidak setuju dengan penghitungan zona nilai tanah BKAD Kabupaten Sleman maka wajib pajak dipersilahkan menghadap langsung ke Kantor BPKAD untuk klarifikasi tentang kebenaran harga transaksi riil dengan membawa bukti-bukti otentik seperti kwitansi asli jual beli atau bukti

${ }^{8}$ Peraturan Daerah Kabupaten Sleman Nomor 14 Tahun 2010 tentang Bea Perolehan Hak atas Tanah dan Bangunan. 
seluruh tranfer pembayaran jual beli. ${ }^{9}$ Lemah dan kurang tegasnya sanksi yang diberikan oleh Pihak BKAD Kabupaten Sleman ini mengakibatkan adanya kecenderungan wajib pajak untuk merekayasa harga transaksi sebenarnya demi kepentingan wajib pajak sendiri, hal ini menggambarkan pemungutan BРНTB di Kabupaten Sleman belum optimal dari segi penerimaan pajak daerah dan proses penelitian BPHTB yang membutuhkan banyak waktu.

\section{Penutup}

Sebagai garda terdepan Peran PPAT dalam optimalisasi pembayaran BPHTB di Kabupaten Sleman yaitu memberikan informasi yang akurat kepada wajib pajak tentang dasar pengenaan BPHTB dan menghimbau kepada para pihak untuk memberikan data informasi yang riil akan besaran harga jual beli tanah yang sebenarnya sebagai dasar pengenaan dalam penghitungan pajak BPHTB. Dengan besaran harga jual beli tanah yang sesuai dengan harga transaksi sebenarnya memungkinkan pembayaran BPHTB jual beli tanah di Kabupaten Sleman sesuai dengan Peraturan Daerah Kabupaten Sleman Nomer 14 Tahun 2010. Sehingga pendapatan daerah Kabupaten Sleman dari sektor pajak dapat optimal.

Kurangnya pengetahuan dan ketidakjujuran dari wajib pajak tentang tatacara pengisian, penghitungan,penelitian dalam pembayaran BPHTB menjadi tugas PPAT untuk menjelaskan dan mengawal wajib pajak dalam proses pemungutan BPHB agar sesuai dengan Perda Kabupaten Sleman. Dalam hal pembayaran BPHTB yang paling riskan untuk disalahgunakan oleh wajib pajak adalah BPHTB peralihan hak atas jual beli tanah, sebab perhitungannya berdasarkan harga transaksi jual beli yang terjadi. Dalam upaya optimalisasi pembayaran BPHTB, calon wajib pajak dihimbau untuk melaksanakan pembayaran pelunasan jual beli tanah dihadapan PPAT Kabupaten Sleman sehingga akan diketahui harga jual beli sebenarnya bukan harga yang direkayasa oleh para pihak untuk menghindari pajak jual beli yang seharusnya terutang. Sehingga penyalahgunaan sistem self assesment yaitu dengan sengaja para pihak memperkecil harga transaksi jual beli yang sebenarnya dengan kesepakatan tidak baik antar para pihak untuk membuat harga jual beli serendah- rendahnya dari harga jual beli yang sebenarnya demi merekayasa pembayaran BPHTB yang seharusnya terutang dapat diminimalisir.Pemberian saksi yang tegas dari Pemerintah Daerah Kabupaten sleman juga dapat memberikan efek jera bagi wajib pajak yang mencoba untuk mengakali pajak BPHTB demi keuntungan pribadi.

${ }^{9}$ Wawancara dengan Tri Wahyuni Herawati, PPAT Kabupaten Sleman, tanggal 8 Juli 2020. 
Saran yang dapat diberikan yaitu harus adanya koordinasi yang berjenjang antara Pemda Sleman atau BKAD Kabupaten Sleman khususnya dengan seluruh PPAT di Kabupaten Sleman mengenai harga pasar jual beli tanah di seluruh wilayah- wilayah Kabupaten Sleman sebagai acuan dasar zona nilai tanah dalam penghitungan pajak BPHTB guna memudahkan PPAT dalam memberikan informasi yang benar dan akurat kepada calon wajib pajak tentang kepastian penghitungan berapa pajak BPHTB yang harus dibayarkan oleh wajib pajak. Hal ini menjadi kunci terciptanya kepastian hukum bagi pihak pemerintah daerah kabupaten Sleman sendiri maupun pihak wajib pajak, apabila kondisi ini dapat diwujudkan maka akan tercipta optimalisasi pembayaran pajak BPHTB di Kabupaten Sleman dan mempersingkat waktu pengurusan penelitian dan pembayaran BPHTB di Kabupaten Sleman sehingga waktu proses balik nama jual beli tanah akan semakin cepat, trasparan, akurat yang akan menguntungkan bagi masyarakat Kabupaten Sleman pada umumnya atau para pihak yang akan melakukan jual beli tanah khususnya di Kabupaten Sleman.

Perlu adanya sosialisasi tentang sanksi yang tegas berdasarkan Perda Nomor 14 Tahun 2010 tentang BPHTB yang berlaku melalui PPAT sebagai Pejabat terdepan yang secara langsung berhadapan dengan wajib pajak. Bahwa peran aktif PPAT Kabupaten Sleman sebagai jembatan penghubung dalam memberikan informasi yang akurat setelah adanya kordinasi berjenjang dengan pihak BKAD kabupaten Sleman tentang sanksi, tata cara penghitungan Pemungutan BPHTB serta peran aktif PPAT dalam meminta kejujuran informasi dari wajib pajak tentang harga transaksi jual beli yang sebenarnya mendorong terciptanya optimalisasi dan evisiensi pemungutan BPHTB serta kepastian hukum bagi wajib pajak di Kabupaten Sleman.

\section{Daftar Pustaka}

\section{Buku}

Agus Salim, Teori dan Paradigma Penelitian Sosial, Tiara Wacana, Yogyakarta, 2006.

Marihot Pahalamana Siahaan, Bea Perolehan Hak Atas Tanah dan Bangunan: Teori dan Praktek, RajaGrafindo Persada, Jakarta, 2003.

Peter Mahmud Marzuki, Penelitian Hukum, Kencana Prenada Media Grup, Jakarta, 2011.

Soerjono Soekanto, Pengantar Penelitian Hukum, UI Press, Jakarta, 2002.

Zainuddin Ali, Metode Penelitian Hukum, Sinar Grafika, Jakarta, 2009.

\section{Peraturan Daerah}

Peraturan Daerah Kabupaten Sleman Nomor 14 Tahun 2010 tentang Bea Perolehan Hak atas Tanah dan Bangunan. 